Семененко Л. М., кандидат філологічних наук, доцент, Криворізький державний педагогічний університет

\title{
КОНЦЕПТ МИСТЕЦТВА ТА МИТЦЯ В ПОВІСТІ ЛЮБОВІ ЯНОВСЬКОЇ «ТАЙНА НАШОЇ ПРИНЦЕСИ»
}

У статті аналізуються особливості вияву кониепту мистецтвва та мития в повісті «Тайна нашої Принцеси» української письменниці кінця XIX - початку XX століть Любові Олександрівни Яновської. Основна увага автора акиентується на поєднанні модерністського та народницького підходів у розкритті постаті мития та сутності й завдань мистецтва. Розглядаються такі аспекти аналізованого конщепту: мистецтво як абсолютна иінність, талант та иіна його реалізащії; авторка торкається гендерної проблематики, розкриває різні грані психологї мития та психологї творчості загалом. У статті вказано, щзо кониепт мистецтва й мития у повісті Любові Яновської $\epsilon$ багатоплановим та актуальним для літературного контексту ї̈ доби.

Ключові слова: концепт, мистецтво, митець, реалізм, модернізм, народництво, психологізм.

В статье анализируются особенности проявления конщепта искусства и твориа в повести «Тайна нашей Принцессы» украинской писательницы конца XIX - начала XX веков Любови Александровны Яновской. Основное внимание автора акиентируется на сочетании модернистского и народнического подходов в раскрытии личности автора и сущности $и$ задач искусства. Актуализируются такие аспекты рассматриваемого концепта: искусство как абсолютная ценность, талант и иена его реализации; автор касается гендерной проблематики, раскрывает разные грани психологии твориа и психологии творчества в целом. В статье указано, что концепт искусства и художника в повести Любови Яновской является многоплановым и актуальным для литературного контекста ее эпохи.

Ключевые слова: концепт, искусство, творец, реализм, модернизм, народничество, психологизм.

This article analyzes peculiar manifestation of the art and artist concepts in the short story «Mystery of our Princess» written by Ukrainian writer of the late XIX - early XX centuries Lyubov Yanovsky. This paper focuses on the combination of modernist and populist approaches in disclosing the figure of the artist and art essense and objectives. This reserch reveals the following aspects of the above mentioned concepts: art as an absolute value, talent and the cost of itsimplementation. The author covers gender problems and represents different traits of artist psychology and art creativity psychology in general. The article states that the art and artist concepts in the story of Lyubov Yanovska are an interdisciplinary and relevant to the literary context of the athor's times.

Keywords: concept art, artist, realism, modernism, populism, psychology.

Літературний процес в Україні кінця XIX - початку XX століття відзначався складністю та неоднозначністю мистецько-культурних дискурсів. У цей час літературними діячами провадилися активні творчі пошуки, орієнтовані, передусім, на здобутки європейських культур та літератур. Поруч iз яскраво вираженими модерними тенденціями в літературі спостерігається тяжіння авторів до національної художньо-зображальної традиції, продовження 
використання народницького літературного канону. Частина українських авторів цієї складної переламної доби намагалася поєднати традиції та новаторство, використовуючи у своїй творчості як художні здобутки реалізму, так i нові підходи до художнього осмислення світу. Одним із таких письменників є Любов Олександрівна Яновська, творчий доробок якої, хоч і не був вилучений із літературного процесу, проте як значущий тривалий час не розглядався. Любов Яновська постає як автор ряду драматичних та прозових творів, у яких своєрідно відбилися провідні тенденції доби, виявлені на різних рівнях. Авторка звертається у своїх художніх текстах до соціальних, національних, моральних, гендерних, мистецьких проблем, презентуючи їх широко та багатоаспектно. На цю особливість творчості Любові Яновської не раз указували дослідники [Приймак 2007; Сінько 1962; Шумило 1991]. Значне місце у прозовій творчості письменниці посідає мистецька проблематика, загалом актуальна для всієї української літератури порубіжжя XIX і XX століть. Складність та неоднозначність концептуальних вирішень проблеми мистецтва та митця яскраво презентована в повісті Любові Яновської «Тайна нашої Принцеси».

Отже, мета статті полягає у з’ясуванні семантичного та функціонального навантаження концепту мистецтва та митця в повісті «Тайна нашої Принцеси» Любові Олександрівни Яновської.

Актуалізація концепту мистецтва в повісті відбувається передусім через постать талановитої дівчини Тетяни («принцеси фон Тетянівки» «Вашої ясновельможності» - так називають іiі в родині), яка має свої погляди на мистецтво і прагне реалізувати ці погляди у власній творчості. Тетяна навіть зовні явно відрізняється від інших членів своєї родини, що не раз підкреслюється наратором: «Гінка, статурна, 3 розкішним пухким світлорусявим волоссям, голубими, ясними очима, високим білим чолом, з спокійними, обережними руками, вона робила дійсно вражіння хоч світлої, але все ж таки досадної плями в гнізді тих одноманітних, чорнявих, чорнобривих, карооких, круглих, угодованих, завжди галасливих, непосидячих, веселих нащуадків 
небіжчика Михайличенка» [Яновська 1991:644]. Дівчина настільки відрізнялася від своїх рідних, що «чужі люди завжди вважали ї̈ за гостю» [Яновська 1991:644]. Одяг Тетяни теж відрізняється від традиційного, він покликаний підкреслити незвичайність іï як особистості: «Вона мала звичку носити на плечах тонісіньку довжелезну білу намітку; кінцуі ї̈ прикро-прикро обгортала навколо свого стану: щуо більщ захоплювалася або хвилювалася, то все дужче натягала ту намітку на плечі» [Яновська 1991:645]. Незважаючи на юний вік, Тетяна наділена певною життєвою мудрістю, яка не раз підкреслюється у творі. Важливо, що вона готова слухати інших, цікавиться їх думками, проте, має силу подавати власну оцінку подій та явищ, висловлювати власну думку, хай і з певною категоричністю: «Прийде, було, до нас, отак запеленана, стиха привітається, стане коло дверей, обіпреться об лутку, коли ми в кімнаті, або об дерево, коли ми в саду, і слухає наші розмови. Якщуо поділяє наші думки, - слухає уважно, з великим задоволенням, коли ж хтось де, на ї̈ думку, схибне, - одразу спиняє, поправляє, починає доводити й доти доводить, доти тлумачить, поки Марія не спалахне та не прожене ї̈ геть у «володіння Принцеси». Тоді вона повертає спину $i$ йде мовчки - геть од нас у сад або в поле. На короткий мент цуе наче неприємно, але в глибині серияя свого ми дякуємо Марії за те, щзо «вирядила» наче цүілком чужу нам людину. Тетяна відокремилася од нас у комору й жила там самотнім, не зрозумілим для нас життям» [Яновська 1991:645]. Постійне підкреслення оригінальних, романтизованих портретних та особистісних рис персонажа постає своєрідним прологом до розкриття бачення Тетяною сутності мистецтва та прагнень реалізуватися у творчості. Погляди на мистецтво, презентовані через бачення Тетяни, явно співзвучні до мистецьких шукань культури раннього українського модернізму, для яких характерна така ж апологія краси: «Яке велике щзастя $\epsilon$ людям - ота здібність відчувати красу скрізь, де й як би вона не виявлялася. Дано нам очі, вуха, ніс, навіть язик, $i$ все те наче задля того, щзоб ми могли помітити красу, пережити хвилини естетичного почуття. Здебільшого люди не звертають на цее уваги, але я не можу, бо всяка краса, все те, щуо ми звемо 
гарним, вражає мене до самого серия, бо очі мої, вуха, ніс - усе ие дає мені таку велику насолоду, таке велике щзастя, хоча між ними й буває конфлікт» [Яновська 1991:648]. Показовим є те, що мистецтво в такому світогляді виступає на перший план і явно превалює над наукою. Здатність бачити й відчувати красу позиціонується як абсолютна цінність, притаманна не кожному. В одному з діалогів Тетяна як апологет мистецтва відверто зізнається: «Чи то через мій малий розум, чи через брак освіти, всі наукові винаходи, такі цุінні для культури та цчивілізащ̧ї, мене зовсім не обходять $і$ ні краплі не вражають. Я можу изілими днями з захопленням дивитися, як жайворонок або голуб купаються в небесній блакиті, ци дивлюся иілком байдуже, коли над головою пролітає аероплан, ніяк не иџікавлячись ні його конструкцією, ні тими людьми, щзо в ньому летять. Ні, розуму своєму я не маю за щзо дякувати. Зате очі, вуха, ніс, язик...» [Яновська 1991:648].

Важливо, що Тетяна як ключова фігура твору, здатна бачити, відчувати та сприймати красу, не лише ставить перед собою мету служіння мистецтву i красі, але й готова наполегливо працювати для цієї мети. У повісті не раз підкреслюється не лише піднесеність дівчини, але й iï здатність оцінювати власні успіхи, а, передусім, велика працездатність: «Ніщо не виходить у мене так, як я хочу. Я дивлюся в дзеркало і бачу, щзо все не так, не те. А цуе, знаєи, так боляче, до сліз доходить, бо від власного життя я зовсім відиуралася, воно дріб'язкове; я можу жити життям тільки тих героїв, моїх славетних героїв. I справді, чого варті ті дрібненькі переживання, порівнюючи до трагедій великих, хоч і нещуасних людей. Знаєщ, коли я слухаю твори Бетховена, дивлюсь на малюнки Рафаеля або читаю Шекспіра, я палко молюся. Молюся без слів, але кожним атомом душі, серия, тіла й дякую природі за те, щуо вона сотворила мене людиною, яка може відчувати всяку красу. Може, думаєщ, я хочу вчитися співати заради слави? Зовсім ні. Я хочу вчитися тільки задля того, щуоб добре виконувати твори славетних маестро, тільки для цуього хочу вчитися. У изьому бачу своє призначення, мету всього свого життя» [Яновська 1991:647]. Дівчина наполегливо вчиться акторській майстерності, іiі 
не лякає самотність у «володіннях Принцеси», тобто явна відчуженість від звичного оточення, оскільки вона має мету й докладає значних зусиль, щоб цієї мети досягти (читає книги, грає ролі, репетирує наодинці). Дівчина чітко усвідомлює необхідність і значення виконавської майстерності: «Коли в n’ $\epsilon$ сі героїні треба падати непритомною, то я учуся падати на изьому сіннику, бо не можна ж падати, як падає колода або сніп, а треба так упасти, щуоб навіть сукня лягла рівними складками» [Яновська 1991:647]. Тетяна чітко бачить свій подальший шлях для реалізації у творчості: вона прагне навчатися в консерваторії, для неї «иее не примха, а велика жагуча потреба душі» [Яновська 1991:655]. Дівчина навіть вимагає у рідних кошти для навчання, а коли з'ясовується, що мати не може оплатити навчання і Тетяни, i iї сестри, то егоїзм артистки виступає на перший план. Тетяна не погоджується поступитися, для неї очевидними є лише власні інтереси. Задля досягнення мети дівчина готова навіть принести в жертву всі родинні стосунки. Коли знаходиться меценат, готовий опікуватися іï долею, Тетяна втікає 3 дому. Довгий час родина не знає, що із нею сталося. Любов Яновська детально описує тривалі пошуки дівчини, ініційовані сім'єю Тетяни, показує, як поховали дівчину, на неї схожу, і навіть поставили надгробок, протиставляючи в такий спосіб егоїзм та сталість і важливість традиційних родинних стосунків.

Важливою складовою концепту мистецтва і митця у повісті «Тайна нашої Принцеси» постає проблема таланту та його реалізації. У повісті не раз наголошується, що Тетяна має значний талант, а справжнє мистецтво має вплив на будь-яку аудиторію (таку абсолютизацію мистецького впливу на реципієнтів можна трактувати як безумовний маркер раннього українського модернізму). Співацький талант Тетяни має незаперечний вплив на слухачів, що виявляється в різних ситуаціях і в оцінках різних персонажів. Зокрема, нараторка оцінює іiі талант як всеохоплюючий і потужний: «Ми несвідомо линули до неї всім серц̧ем своїм, всіма найкращчими своӥми почуттями - цее тоді, коли вона співала. Надзвичайно дужий, на диво чистий, дзвінкий, а разом з тим м'який голос наче таӥв у собі чарівну силу. Найбільше обурення, найлютіма досада на неї враз 
ізникали, як тільки залунає, було, десь, зблизу чи здалека, ї̈ голос. Хотілося кинути тоді все, бігти до неї, сісти десь долу - у ніг ї̈, понести їй квітів, віддати їй усе, щуо маєш найдорожчого, стати рабом ї̈-аби вона не уривала своєї пісні, аби душа, знесена на крилах ї̈ пісні кудись в далеку, чисту блакить, спочила гаразд од усіх дрібних, брудних турбот життєвих. I коли вона було приходила швидко після співів, очі ї̈ сяяли, вся вона була немов оточена якимсь світлим ореолом; вона здавалася тоді вищуою, щуе статурнішою, і так личило їй тоді бути мовчазною, неприступною, $i$ так охоче, здається, признав би кожний за безапелячійну правду всяке ї̈ слово, яке вона в ту хвилину прорекла б!» [Яновська 1991: 651]. Брат Борис оцінює голос сестри так: «У Тетяни такий голос, щуо навіть селяни заслуховуються»[Яновська 1991:657]. Олесь, вчитель співів та фортепіано, а надалі - меценат і своєрідний опікун Тетяни, теж оцінив голос маленької дівчинки дуже високо: «Це ж перлина, ие ж самородок» [Яновська 1991:669]. Показово, що Тетяна цілком свідома свого таланту та його можливостей, дівчина має високу самооцінку та яскраво виявлені мистецькі амбіції: «Я людина з великим талантом, - мовила вона, -я сама своєю душею відчуваю своє призначення, передбачаю ту височінь, на яку я можу звестися в мистецтвві, й навіть бувають хвилини, коли я можу творити, можу складати нові пісні, такий талан - дорогоиінна річ, його гріх занехаювати, його треба берегти, пестити... Я не соромлюся ні голосу свого, ні артистичного хисту свого!»[Яновська 1991:660]. Такий підхід поруч із чітко поставленою метою та надзвичайною працездатністю, зрештою, стає запорукою успіху дівчини як визнаної співачки.

Однак, як уже вказувалося вище, реалізація навіть визначного таланту, на думку авторки, потребує значної наполегливості та не менш значних жертв.

Приставши на пропозицію мецената Олеся, Тетяна вступає i закінчує консерваторію як Галина Зук, під цим же іменем вона гастролює. Прикметно, що пан Олесь постає як справжній шанувальник мистецтва та істинний меценат (мрія не одного покоління українських митців), про що відразу повідомляє Тетяні: «Тепер, моя голубонько, щуоб ви ніколи не забували, щуо маєте такого 
приятеля та заступника, як я. Я одвезу вас у консерваторію, звідтіля ви вийдете славетною співачкою, а потім будете жити, оточені розкішшю та славою, я ж буду повсякчас вам у пригоді, як батько, як приятель, як заступник. Як єдину нагороду за всі мой клопоти буду вас прохати: щуоб ви співали по концертах мої романси»[Яновська 1991:697]. Слова мецената справдилися: Тетяна здобула славу й визнання. Читача інформується про це вже не звичною традиційною оповіддю нараторки, а словами чоловіка, який слухав спів Тетяни в театрі і був настільки захоплений, що закохався у співачку: «Весь театр тремтів від оплесків, бо то не були оплески наших клакерів, а то були оплески доведених до екстазу справжніх знавців штуки та співів. <..> Її називали «соловейком Украӥни». Мені здавалося, щуо вона не тільки соловейко, а блакитне небо, ясні зорі, килим квітів Украӥни, й мені здавалося, щуо вона така ж недосяжна, як те небо, як ті зорі, щзо вона навіть $i$ не людина, а якась фея» [Яновська 1991:695]. Наведена оцінка ще раз підкреслює атрибутивну ознаку модернізму в розкритті концепту мистецтва абсолютизацію його впливу на слухача, читача, глядача. Важливо, що таку захоплену оцінку співачки дає саме чоловік, адже здобуття слави та реалізація таланту традиційно вважалися прийнятними для чоловіків, а не для жінок, яким відводилися ролі хранительки сімейного вогнища, матері, бабусі тощо. Вибір персонажа-жінки в цьому аспекті бачиться не випадковим, оскільки проблема реалізації таланту та пошуку визнання була близькою самій письменниці. I коли співачка Тетяна зізнається: «Я така щзаслива, щзо коли б щзастя було чимсь конкретним і коли б його можна було б різати на скибки, то його можна було б роздати десяти душам $i$ зробити десять чоловіків щзасливими» [Яновська 1991:697], то іiі слова звучать як гасло перемоги жіночої самореалізації в чоловічому світі.

Проте, Любов Яновська залишається цілком традиційною, коли говорить про почуття гострої ностальгї, яку переживає іï alter ego Тетяна: «Туга по рідному краю, будь той край на острові серед крижаного моря або серед пісків Сахари, - не порожні слова й не вигадка, а почуття таке велике, таке 
могутнє, таке реальне, щуо я не знаю, до якого почуття його можна прирівняти! <..> ніякі діадеми, ніякі вінки не задовольняють тебе, бо в них нема рідних волошок; ніякі оплески не тішать, бо не чуєш оплесків рідного брата або сестри. Чуже соние не гріє, чуже небо не вабить...» [Яновська 1991:697-698]. У такий спосіб актуалізується народницька ідея про те, що митець не повинен відриватися від своєї батьківщини, що його творчість повинна надихатися рідним краєм.

Отже, актуалізуючи концепт мистецтва та митця у повісті «Тайна нашої Принцеси», авторка розглядає такі його аспекти: мистецтво як абсолютна цінність, талант та ціна його реалізації, торкається гендерної проблематики, розкриває різні грані психології митця та психологї творчості загалом. Важливо, що концепт мистецтва маркується як модерністськими, так i народницькими тезами, чим визначається оригінальність прозового доробку Любові Олександрівни Яновської.

\section{БІБЛІОГРАФІЯ}

Приймак 2007 - Приймак I. В. Творчість Любові Яновської в літературному процесі кінця XIX - початку XX століть : автореф. дис. на здобуття наук. ступеня к. філол. наук : спец. 10.01.01 - українська література / I. В. Приймак. - Львів, 2007. - 27 с.

Сінько 1962 - Сінько Г. Ю. Любов Яновська : Життя і літературна діяльність / Г. Ю. Сінько. - К. : АН УРСР : Інститут літератури ім. Т. Г. Шевченка, 1962. - 95 с.

Шумило 1991 - Шумило Н. М. Подолати в душі зло... / Н. М. Шумило // Л. О. Яновська. Твори : в 2 т. - Т. 1 : Оповідання, повісті. - К. : Дніпро, 1991. C. 5-28.

Яновська Л. О. Мій роман / Л. О. Яновська // Л. О. Яновська. Твори : в 2 т. - Т. 1 : Оповідання, повісті / [упорядн. та авт. передм., приміт. : Н. М. Шумило]. - К. : Дніпро, 1991. - 718 с. 